\title{
Enantiospecific approach toward pentalenolactone
}

\author{
Sebastián A. Testero, Rolando A. Spanevello* \\ Instituto de Química Orgánica de Síntesis. Facultad de Ciencias Bioquímicas y Farmacéuticas - Universidad \\ Nacional de Rosario-CONICET, Suipacha 531, S2002LRK Rosario, Argentina.
}

General methods. Melting points were taken on a Leitz Wetzlar Microscope Heating Stage, Model 350 apparatus, and are uncorrected. Optical rotations were recorded with a Jasco DIP 1000 polarimeter. IR spectra were recorded on a Shimadzu IRPrestige 21 FT or Beckman Acculab 8 spectrometers. High resolution mass spectrometry measurements were performed using a Waters AutoSpect equipment or Applied Biosystems MS. Nuclear magnetic resonance spectra were recorded on a Bruker AC-200 spectrometer with $\mathrm{Me}_{4} \mathrm{Si}$ as internal standard and chloroform- $d$ as solvent. Reactions were monitored by TLC on 0.25 mm E. Merck Silica Gel plates (60F254), using UV light and anisaldehyde- $\mathrm{H}_{2} \mathrm{SO}_{4}-\mathrm{AcOH}$ as detecting agents. Flash column chromatography, using E. Merck Silica Gel 60H, was performed by gradient elution created by mixtures of hexanes and increasing amounts of EtOAc. Reactions were performed under an argon atmosphere with dry, freshly distilled solvents under anhydrous conditions, unless otherwise noted. Yields refer to chromatographically and spectroscopically ( ${ }^{1} \mathrm{H}$ NMR) homogeneous materials, unless otherwise stated.

For the synthesis of aldehyde 4 in $46 \%$ overall yield see reference 9 . The use of aldehyde 4 without column chromatography purification improved the overall published procedure.<smiles>COC1C=C(C=O)C2OC(C)OC[C@H]2O1</smiles>

4

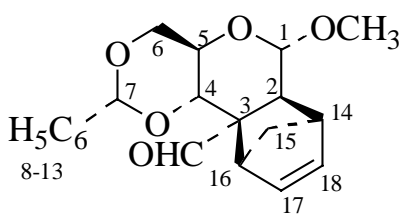

5 
Cycloadduct (5). Aldehyde 4 (3.750 g, $13.59 \mathrm{mmol})$ was dissolved in dry acetonitrile (136 $\mathrm{mL}$ ) and stirred during 30 minutes with anhydrous $\mathrm{LiClO}_{4}(7.2345 \mathrm{~g}, 67.95 \mathrm{mmol})$. Freshly cracked cyclopentadiene $(9.125 \mathrm{~mL}, 135.90 \mathrm{mmol})$ was added under inert atmosphere at room temperature. The reaction was completed after $18 \mathrm{hs}$. The mixture was diluted with ethyl ether and washed with water. The organic layer was dried over $\mathrm{Na}_{2} \mathrm{SO}_{4}$, and concentrated under vacuum. Flash chromatography to remove the excess of bicyclopentadiene afforded compound 5 (4.0480 g, $11.84 \mathrm{mmol})$ in $85 \%$ yield.

5: colorless oil.

$[\alpha]_{\mathrm{D}}^{25}=+55.7\left(\mathrm{c} 1.01, \mathrm{CHCl}_{3}\right)$.

IR (film): $v_{\text {máx }}\left(\mathrm{cm}^{-1}\right)=2990,2930,1730$ (CO), 1465, 1386, 1109, 1072, 1039, 758, 708.

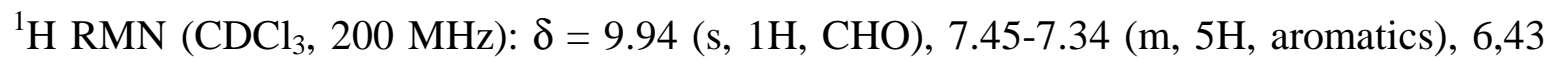
(sa, 2H, vinylic), 5.40 (s, 1H, benzylic), 4.34 (d, J= $3.7 \mathrm{~Hz}, 1 \mathrm{H}$, anomeric), 4.27 (dd, $\mathrm{J}_{1}=$ $\left.10.4 \mathrm{~Hz}, \mathrm{~J}_{2}=5.0 \mathrm{~Hz}, 1 \mathrm{H}, \mathrm{C}-6 \mathrm{H}_{\mathrm{eq}}\right), 3.81(\mathrm{~m}, 1 \mathrm{H}, \mathrm{C}-5 \mathrm{H}), 3.53\left(\mathrm{dd}, \mathrm{J}_{1}=\mathrm{J}_{2}=10.4 \mathrm{~Hz}, 1 \mathrm{H}, \mathrm{C}-6\right.$ $\mathrm{H}_{\mathrm{ax}}$ ), 3.51 (d, J=10.4 Hz, 1H, C-4 H), 3.41 (bs, 1H, C-16 H), 3.36 (s, 3H, OCH $)_{3}, 3.00$ (bs, $1 \mathrm{H}, \mathrm{C}-14 \mathrm{H}), 2.78(\mathrm{t}, \mathrm{J}=3.7 \mathrm{~Hz}, 1 \mathrm{H}, \mathrm{C}-2 \mathrm{H}), 1.50\left(\mathrm{dt}, \mathrm{J}_{1}=9.0 \mathrm{~Hz}, \mathrm{~J}_{2}=1.7 \mathrm{~Hz}, 1 \mathrm{H}, \mathrm{C}-15 \mathrm{H}_{\mathrm{a}}\right.$ ), $1.21\left(\mathrm{~d}, \mathrm{~J}=9.1 \mathrm{~Hz}, 1 \mathrm{H}, \mathrm{C}-15 \mathrm{H}_{\mathrm{b}}\right)$.

${ }^{13} \mathrm{C} \mathrm{RMN}\left(\mathrm{CDCl}_{3}, 50 \mathrm{MHz}\right): \delta=201.8(\mathrm{CHO}), 138.1$ (C-vinylic), $137.0(\mathrm{C}-i p s o), 136.8(\mathrm{C}-$ vinylic), 129.1 (C-para), 128.2 (2C, ortho), 126.1 (2C, meta), 101.9 (C-7), 101.8 (C-1), 80.4 (C-4), 69.6 (C-6), 60.9 (C-5), 60.8 (C-3), $55.0\left(\mathrm{OCH}_{3}\right), 47.0$ (C-15), 46.9 (C-2), 46.0 (C-14), 45.5 (C-16).

HRMS m/z 342,1467 [(M+); calcd for $\left.\left.\mathrm{C}_{20} \mathrm{H}_{22} \mathrm{O}_{5}: 342,1472\right)\right]$.

LRMS (I.E.): m/z (int. rel.): 159 (57), 122 (27), 105 (100), 85 (53), 69 (68), 55 (37), 43 (45).

Anal. Calcd for $\mathrm{C}_{20} \mathrm{H}_{22} \mathrm{O}_{5}: \mathrm{C}=70,16, \mathrm{H}=6,48, \mathrm{O}=23,36$. Found $\mathrm{C}$ 70,06, H 6,52. 
<smiles>COC1O[C@@H]2COC(C)OC2[C@]2(C)[C@H]3C=C[C@@H](C3)[C@]12C</smiles>

5

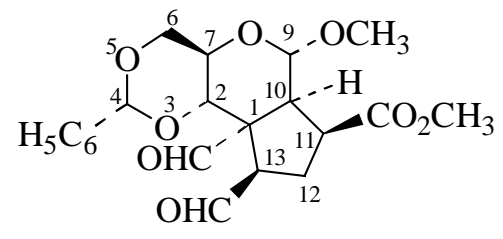

9

$(1 S, 2 S, 4 R, 7 R, 9 S, 10 S, 11 S, 13 R)$ 1, 13-dicarbaldehyde-9-methoxy-4-phenyl-3,5,8trioxatricyclo $\left[8.3 .0^{1,10} .0^{2,7}\right]$ tridecane-11-carboxylic acid methyl ester (9) (IUPAC numbering was only used for this compound) The cycloadduct 5 (880.5 mg, $2.57 \mathrm{mmol})$ was dissolved in a 5:1 mixture of $\mathrm{CH}_{2} \mathrm{Cl}_{2}: \mathrm{MeOH}(5 \mathrm{ml})$ and solid $\mathrm{NaHCO}_{3}(865 \mathrm{mg}, 10.3$ mmol) was added. The suspension was cooled to $-78{ }^{\circ} \mathrm{C}$ and an ozone stream was bubbled through the suspension as it was stirred. Ozone addition was stopped when complete consumption of (5) was observed by TLC analysis. The mixture was then flushed with argon, and $\mathrm{NaHCO}_{3}$ was removed by filtration. The filtrate was concentrated in vacuo to give the crude as colorless oil, which was taken up in $\mathrm{CH}_{2} \mathrm{Cl}_{2}(13 \mathrm{ml})$. The mixture was cooled to $0{ }^{\circ} \mathrm{C}$, and acetic anhydride $(1.2 \mathrm{ml}, 12.85 \mathrm{mmol})$ and triethylamine $(0.5 \mathrm{ml}, 3.08$ mmol) were added. The mixture was stirred at room temperature for $1 \mathrm{~h}$ and then partitioned between diethyl ether and, sequentially, $0.5 \mathrm{M}$ aqueous $\mathrm{HCl}, 0.625 \mathrm{M}$ aqueous $\mathrm{KOH}$, and brine. The combined organic extract was dried $\left(\mathrm{Na}_{2} \mathrm{SO}_{4}\right)$ and concentrated in vacuo to give essentially pure $9(960.5 \mathrm{mg}, 92.3 \%)$.

9: colorless oil.

$[\alpha]_{\mathrm{D}}^{21}=-20.4\left(\mathrm{c} 1.13, \mathrm{CHCl}_{3}\right)$.

IR (film): $v_{\text {máx }}\left(\mathrm{cm}^{-1}\right)=2926,2864,1724(\mathrm{CO}$, broad $), 1452,1438,1372,1212,1174,1130$, $1086,962,758$.

${ }^{1} \mathrm{H}$ NMR $\left(\mathrm{CDCl}_{3}, 200 \mathrm{MHz}\right): \delta=10.23$ (s, 1H, C-1-CHO), 9.65 (s, 1H, C-13-CHO), 7.377.31 (m, 5H, aromatics), 5.48 (s, 1H, C-4 H), 4.90 (s, 1H, C-9 H ), 4.33-4.21 (m, 2H, C-6 $\left.\mathrm{H}_{\mathrm{eq}}, \mathrm{C}-7 \mathrm{H}\right), 4.08$ (d, J=9.7 Hz, 1H, C-2 H), 3.72 (s, 3H, $\left.\mathrm{CO}_{2} \underline{\mathrm{C}}_{3}\right), 3.73-3.66$ (m, 1H, C-6 
$\left.\mathrm{H}_{\mathrm{ax}}\right), 3.65-3.41(\mathrm{~m}, 1 \mathrm{H}, \mathrm{C}-13 \mathrm{H}), 3.39$ (s, 3H, C-9-OC$\left.{ }_{3}\right), 3.35-2.96$ (m, 2H, C-11 H, C-12

$\left.\mathrm{H}_{\mathrm{a}}\right), 2.70(\mathrm{~d}, \mathrm{~J}=11.4 \mathrm{~Hz}, 1 \mathrm{H}, \mathrm{C}-10 \mathrm{H}), 2.16-1.97\left(\mathrm{~m}, 1 \mathrm{H}, \mathrm{C}-12 \mathrm{H}_{\mathrm{b}}\right)$.

${ }^{13} \mathrm{C} \mathrm{NMR}\left(\mathrm{CDCl}_{3}, 50 \mathrm{MHz}\right): \delta=200.8(\mathrm{C}-1-\mathrm{CHO}), 198.6(\mathrm{C}-13-\mathrm{CHO}), 173.9\left(\mathrm{CO}_{2} \mathrm{CH}_{3}\right)$,

136.7 (C-ipso), 128.9 (C-para), 128.1 (2C-ortho), 125.7 (2C-meta), 102.0 (C-4), 96.8 (C9), 73.9 (C-2), 69.2 (C-6), 59.8 (C-7), 58.8 (C-1), 56.2 (C-13), $55.0\left(\mathrm{C}-9-\mathrm{OCH}_{3}\right), 52.8(\mathrm{C}-$ 10), $52.3\left(\mathrm{CO}_{2} \underline{\mathrm{CH}_{3}}\right), 41.6(\mathrm{C}-11), 23.6(\mathrm{C}-12)$.

HRMS m/z 427.13585 [( $\left.\mathrm{M}+\mathrm{Na}^{+}\right)$; calcd for $\left.\mathrm{C}_{21} \mathrm{H}_{24} \mathrm{O}_{8}: 427.13688\right]$.
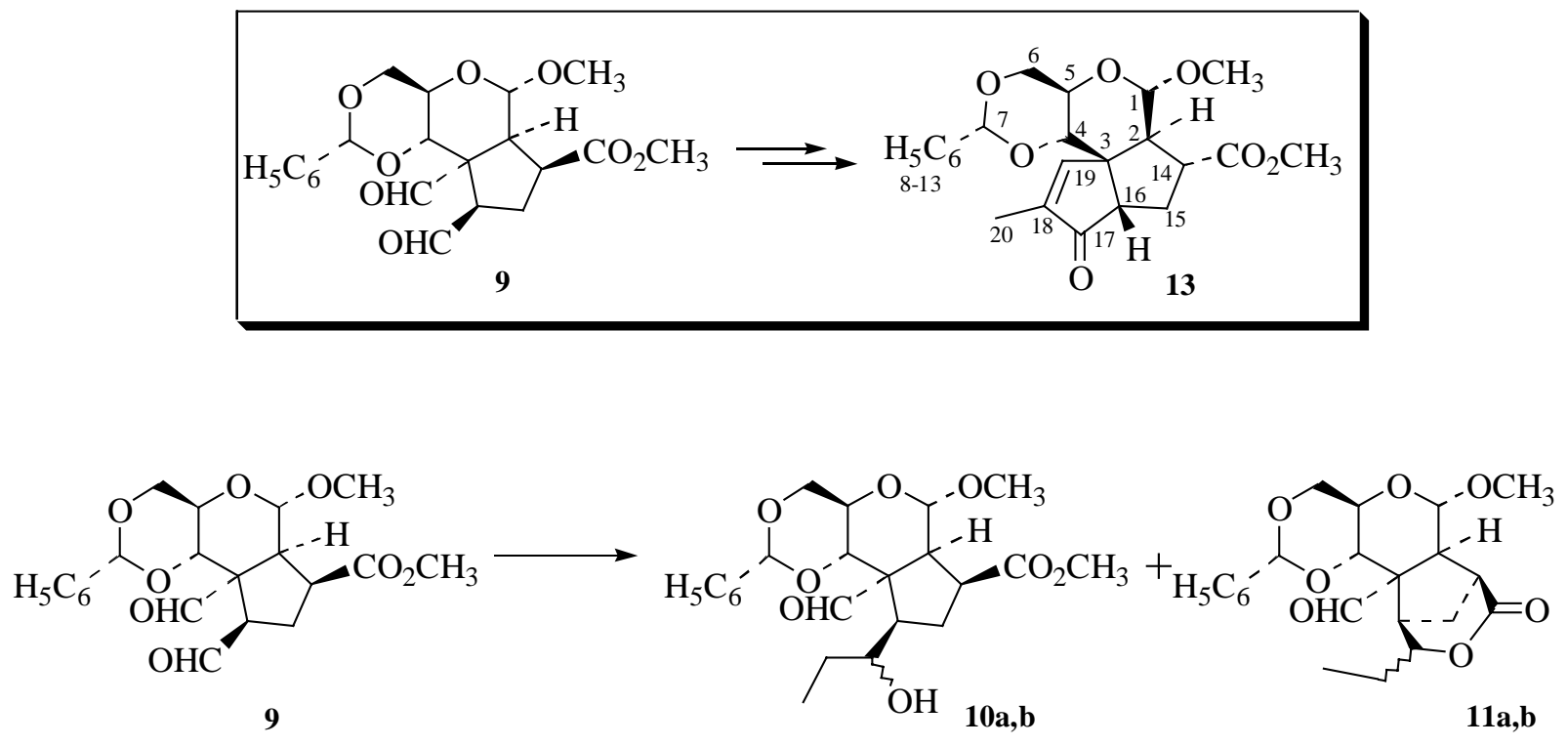

Ethyl alcohols 10a,b and tetracyclic lactones 11a,b. A solution of dialdehyde 9 (960.5 $\mathrm{mg}, 2.377 \mathrm{mmol}$ ) in $33 \mathrm{ml}$ of dry tetrahydrofuran was cooled to $-30^{\circ} \mathrm{C}$ and ethylmangnesium bromide $(0.79 \mathrm{M}, 3.5 \mathrm{ml}, 2.73 \mathrm{mmol})$ was added over a period of $15 \mathrm{~min}$. The reaction mixture was stirred for an additional $50 \mathrm{~min}$. at $-30{ }^{\circ} \mathrm{C}$. The solution was treated with $10 \%$ aqueous $\mathrm{NH}_{4} \mathrm{Cl}$ and extracted with ether. The combined ether extracts were washed with brine, dried $\left(\mathrm{Na}_{2} \mathrm{SO}_{4}\right)$ and the volatiles removed in vacuo to afford 1.038 $\mathrm{g}$ of a mixture of compounds $\mathbf{1 0 a}, \mathbf{b}$ and 11a,b which was used without further purification in the next synthetic transformation. 


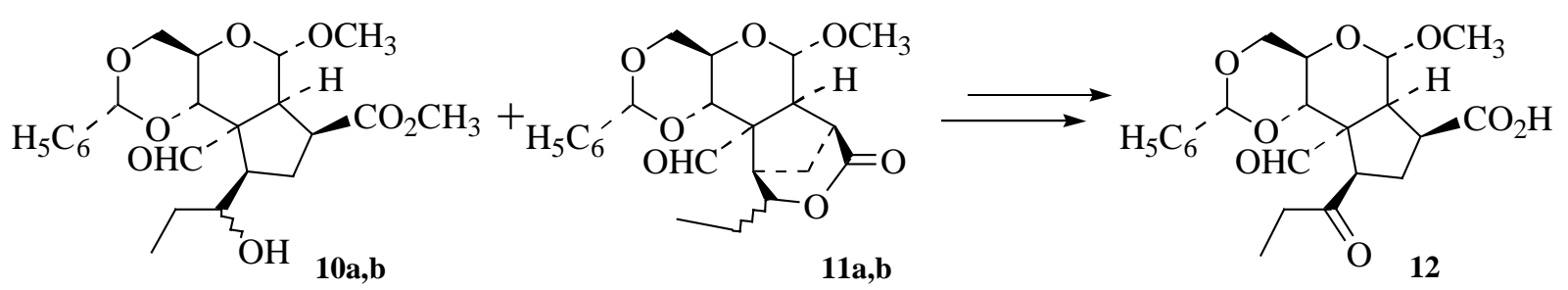

Saponification. The mixture of compounds 10a,b and 11a,b (1.038 g) was dissolved in a 2:1 mixture of $\mathrm{THF} / \mathrm{H}_{2} \mathrm{O}(40 \mathrm{ml})$. The solution was cooled to $0{ }^{\circ} \mathrm{C}$ and $1 \mathrm{~N} \mathrm{LiOH}(7.131 \mathrm{ml}$, $7.131 \mathrm{mmol}$ ) was added with stirring. The mixture was stirred at ambient temperature for $12 \mathrm{~h}$. The solvent was concentrated under reduced pressure and diethyl ether was added. The mixture was poured onto ice and acidified to $\mathrm{pH} 2$ with $1 \mathrm{~N}$ aqueous hydrochloric acid. Diethyl ether extraction, followed by washing the combined ether extract with brine, drying $\left(\mathrm{Na}_{2} \mathrm{SO}_{4}\right)$ and evaporation under reduced pressure furnished $1.013 \mathrm{~g}$ of a residue which was used without further purification in the next synthetic transformation.

Ethyl ketone 12. Jones reagent was added dropwise to a cooled $\left(0{ }^{\circ} \mathrm{C}\right)$ solution of the crude reaction mixture $(1.013 \mathrm{~g})$, obtained from the saponification step, in acetone $(40 \mathrm{ml})$ until the reaction mixture turned light orange. The reaction was stirred $15 \mathrm{~min}$. at $0{ }^{\circ} \mathrm{C}$ and isopropyl alcohol was added to reduce the excess Jones reagent until the reaction mixture turned green. Water was added to the mixture which was vigorously stirred to dissolve the chromium salts and concentrated under reduced pressure (to remove the acetone). Diethyl ether extraction followed by washing the combined ether extract with brine, drying $\left(\mathrm{Na}_{2} \mathrm{SO}_{4}\right)$ and evaporation under reduced pressure gave $0.972 \mathrm{~g}$ of compound 12 which was used without further purification in the next synthetic transformation.

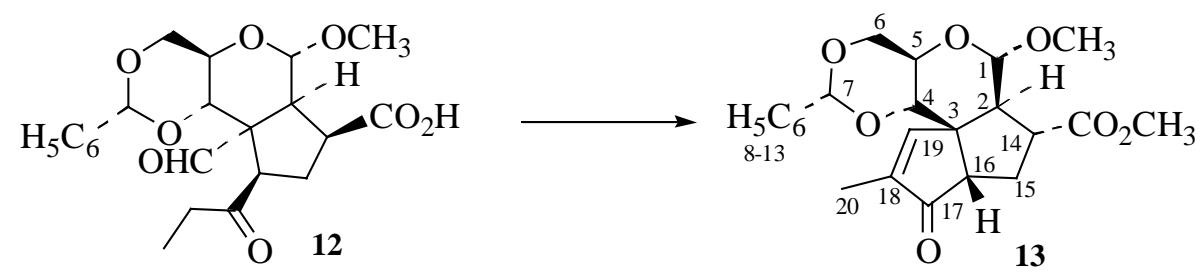


Cyclopentenone (13). To a stirring solution of the ethyl ketone $12(0.972 \mathrm{~g})$ in $35 \mathrm{ml}$ of dry methanol, a potassium hydroxide solution ( $841 \mathrm{mg}, 15 \mathrm{mmol}$ in $35 \mathrm{ml}$ of dry methanol) was added under nitrogen. The reaction was refluxed for $6 \mathrm{~h}$ and then cooled to room temperature. The solvent was concentrated under reduced pressure and diethyl ether was added. The mixture was poured onto ice, acidified to $\mathrm{pH} 2$ with $1 \mathrm{~N}$ aqueous hydrochloric acid and extracted with diethyl ether. The combined organic layers were washed with brine, dried $\left(\mathrm{Na}_{2} \mathrm{SO}_{4}\right)$ and the volatiles removed under reduced pressure. The resulting crude product was dissolved in a 2:3 mixture of $\mathrm{Et}_{2} \mathrm{O}-\mathrm{CHCl}_{3}(20 \mathrm{ml})$ and the solution was cooled to $0{ }^{\circ} \mathrm{C}$. Ethereal solution of diazomethane was added dropwise until the reaction mixture turned light yellow. After stirring $30 \mathrm{~min}$. to $0{ }^{\circ} \mathrm{C}$ acetic acid was added, until disappearance of the yellow coloration, to eliminate the excess of diazomethane. The volatiles were removed in vacuo, and the residual oil $(1.051 \mathrm{~g})$ was purified by flash chromatography to furnish the cyclopentenone $\mathbf{1 3}$ (642 $\mathrm{mg}, 1,55 \mathrm{mmol}$, 66\% from 5, 6 steps).

13: colorless oil.

$[\alpha]_{\mathrm{D}}{ }^{18}=-40.5\left(\mathrm{c} 1.0, \mathrm{CHCl}_{3}\right)$.

IR (film): $v_{\text {máx }}\left(\mathrm{cm}^{-1}\right)=2926,2864,1732$ (CO ester), 1710 (CO ketone), 1650, 1452, 1438, 1380, 1284, 1262, 1168, 1130, 1102, 1050, 1022, 970.

${ }^{1} \mathrm{H}$ NMR $\left(\mathrm{CDCl}_{3}, 200 \mathrm{MHz}\right): \delta=7.49(\mathrm{~d}, \mathrm{~J}=1.31 \mathrm{~Hz}, 1 \mathrm{H}, \mathrm{C}-19 \mathrm{H}), 7.39-7.30(\mathrm{~m}, 5 \mathrm{H}$, aromatics), 5.54 (s, 1H, benzylic), $4.72\left(\mathrm{~s}, 1 \mathrm{H}\right.$, anomeric), 4.35 (dd, $\mathrm{J}_{1}=10.3 \mathrm{~Hz}, \mathrm{~J}_{2}=5.0$ $\mathrm{Hz}, 1 \mathrm{H}, \mathrm{C}-6 \mathrm{H}_{\mathrm{eq}}$ ), 4.14 (ddd, $\left.\mathrm{J}_{1}=9.9 \mathrm{~Hz}, \mathrm{~J}_{2}=9.8 \mathrm{~Hz}, \mathrm{~J}_{3}=5.0 \mathrm{~Hz}, 1 \mathrm{H}, \mathrm{C}-5 \mathrm{H}\right), 3.84-3.68(\mathrm{~m}$, 2H, C-4 H, C-6 $\mathrm{H}_{\mathrm{ax}}$ ), 3.70 (s, 3H, $\mathrm{CO}_{2} \mathrm{C}_{3}$ ), $3.40\left(\mathrm{~s}, 3 \mathrm{H}, \mathrm{OCH}_{3}\right), 3.34-3.18(\mathrm{~m}, 1 \mathrm{H}, \mathrm{C}-14$ H), $2.91\left(\mathrm{dd}, \mathrm{J}_{1}=10.4 \mathrm{~Hz}, \mathrm{~J}_{2}=7.5 \mathrm{~Hz}, 1 \mathrm{H}, \mathrm{C}-16 \mathrm{H}\right), 2.56-2.40\left(\mathrm{~m}, 1 \mathrm{H}, \mathrm{C}-15 \mathrm{H}_{\mathrm{a}}\right), 2.16(\mathrm{~d}, \mathrm{~J}=$ $13.11 \mathrm{~Hz}, 1 \mathrm{H}, \mathrm{C}-2 \mathrm{H}), 1.94\left(\mathrm{ddd}, \mathrm{J}_{1}=13.7 \mathrm{~Hz}, \mathrm{~J}_{2}=11.6 \mathrm{~Hz}, \mathrm{~J}_{3}=7.5 \mathrm{~Hz}, 1 \mathrm{H}, \mathrm{C}-15 \mathrm{H}_{\mathrm{b}}\right.$ ), 1.75 (d, J= $1.31 \mathrm{~Hz}, 3 \mathrm{H}, \mathrm{C}-20 \mathrm{H})$. 
${ }^{13} \mathrm{C} \mathrm{NMR}\left(\mathrm{CDCl}_{3}, 50 \mathrm{MHz}\right): \delta=209.5$ (ketone), 173.2 (ester), 157.5 (C-19), 139.5 (C-18), 137.1 (C-ipso), 129.0 (C-para), 128.1 (2C, ortho), 126.0 (2C, meta), 102.1 (C-7), 98.4 (C1), 78.8 (C-4), 69.3 (C-6), 59.2 (C-5), $55.0\left(\mathrm{OCH}_{3}\right), 54.4$ (C-3), 53.0 (C-16), 53.0 (C-2), $51.9\left(\mathrm{CO}_{2} \mathrm{CH}_{3}\right), 48.4(\mathrm{C}-14), 28.4(\mathrm{C}-15), 10.3(\mathrm{C}-20)$.

HRMS m/z 437.157319 [(M+ Na $\left.{ }^{+}\right)$; calcd for $\left.\mathrm{C}_{23} \mathrm{H}_{26} \mathrm{O}_{7}: 437.157623\right]$.
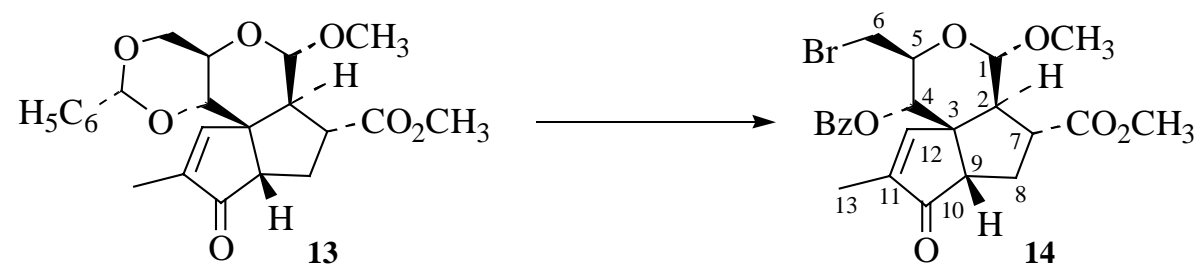

Bromide 14. Barium carbonate $(744 \mathrm{mg}, 3.78 \mathrm{mmol})$ and N-bromosuccinimide $(95.2 \mathrm{mg}$, $0.53 \mathrm{mmol})$ were added to a solution of cyclopentenone $\mathbf{1 3}(184.4 \mathrm{mg}, 0.445 \mathrm{mmol})$ in dry $\mathrm{CCl}_{4}(28.5 \mathrm{ml})$. The mixture was refluxed for $1 \mathrm{~h}$ under normal room-ilumination. The mixture originally colorless, became orange and finally yellow. The suspension was filtered and the filtrate was evaporated. The residue was taken in EtOAc, washed with water, dried with $\mathrm{Na}_{2} \mathrm{SO}_{4}$ and evaporated. The resulting crude product $\mathbf{1 4}$ was used without further purification in the next synthetic transformation.

14: cololess oil.

$[\alpha]_{\mathrm{D}}^{28}=-37.3\left(\mathrm{c} 0.99, \mathrm{CHCl}_{3}\right)$

IR (film): $v_{\text {máx }}\left(\mathrm{cm}^{-1}\right)=2930,1730(\mathrm{CO}$, broad $), 1715(\mathrm{CO}), 1460,1440,1320,1270,1210$, 1190, 1140, 1120, 1100, 1080, 1060, 1040, 720.

${ }^{1} \mathrm{H}$ NMR $\left(\mathrm{CDCl}_{3}, 200 \mathrm{MHz}\right): \delta=7.91-7.87$ (m, 2H, aromatics), 7.62-7.39 (m, 4H, aromatics, C-12 H), 5.29 (d, J= 10.3 Hz, 1H, C-4 H), 4.85 (s, 1H, anomeric), 4.40-4.30 (m, $1 \mathrm{H}, \mathrm{C}-5 \mathrm{H}), 3.70\left(\mathrm{~s}, 3 \mathrm{H}, \mathrm{CO}_{2} \mathrm{C}_{3}\right), 3.51$ (s, $\left.3 \mathrm{H}, \mathrm{OCH}_{3}\right), 3.49-3.23$ (m, 3H, C-6 H, C-7 H), $2.80\left(\mathrm{dd}, \mathrm{J}_{1}=10.4 \mathrm{~Hz}, \mathrm{~J}_{2}=7.3 \mathrm{~Hz}, 1 \mathrm{H}, \mathrm{C}-9 \mathrm{H}\right), 2.59-2.43\left(\mathrm{~m}, 1 \mathrm{H}, \mathrm{C}-8 \mathrm{H}_{\mathrm{a}}\right), 2.20(\mathrm{~d}, \mathrm{~J}=12.92$ 
$\mathrm{Hz}, 1 \mathrm{H}, \mathrm{C}-2 \mathrm{H}), 1.90\left(\mathrm{ddd}, \mathrm{J}_{1}=13.4 \mathrm{~Hz}, \mathrm{~J}_{2}=11.7 \mathrm{~Hz}, \mathrm{~J}_{3}=7.3 \mathrm{~Hz}, 1 \mathrm{H}, \mathrm{C}-8 \mathrm{H}_{\mathrm{b}}\right), 1.76(\mathrm{~d}, \mathrm{~J}=$ $1.12 \mathrm{~Hz}, 3 \mathrm{H}, \mathrm{C}-13 \mathrm{H})$.

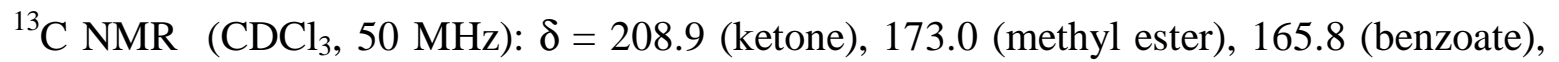
156.6 (C-12), 139.7 (C-11), 133.7 (aromatic), 129.7 (2C, aromatics), 128.5 (3C, aromatics), $98.2(\mathrm{C}-1), 71.1(\mathrm{C}-4), 66.7(\mathrm{C}-5), 55.9(\mathrm{C}-3), 55.4\left(\mathrm{OCH}_{3}\right), 54.0 *(\mathrm{C}-9), 53.1 *(\mathrm{C}-2), 51.9$ $\left(\mathrm{CO}_{2} \mathrm{CH}_{3}\right), 48.1$ (C-7), 32.0 (C-6), 28.4 (C-8), 10.2 (C-13). (* = interchangeable)

HRMS m/z 510.1146 [( $\left.\mathrm{M}+\mathrm{NH}_{4}^{+}\right)$; calcd for $\left.\mathrm{C}_{23} \mathrm{H}_{25} \mathrm{BrO}_{7}: 510.11267\right]$.
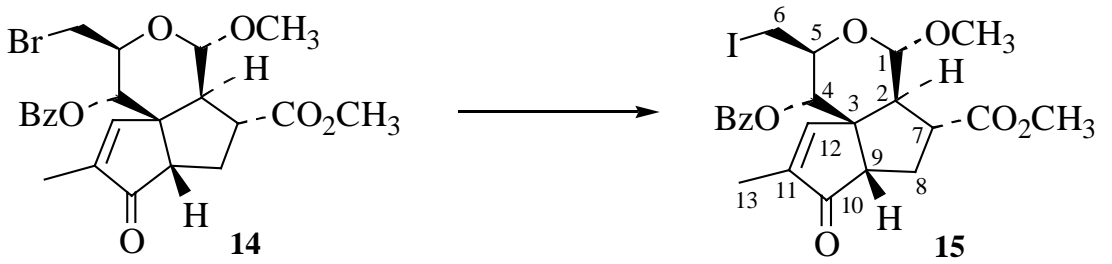

Iodide 15. A mixture of the bromide $14(166.7 \mathrm{mg}, 0.338 \mathrm{mmol})$ and $\mathrm{KI}(335 \mathrm{mg}, 2.02$ mmol) in $\mathrm{N}, \mathrm{N}$-dimethylformamide $(1 \mathrm{ml})$ was stirred for $12 \mathrm{~h}$ at $50{ }^{\circ} \mathrm{C}$. The mixture was poured onto ice and extrated with EtOAc. The solution was washed successively with $5 \%$ aqueous $\mathrm{Na}_{2} \mathrm{~S}_{2} \mathrm{O}_{3}$, and water, and the dried $\left(\mathrm{Na}_{2} \mathrm{SO}_{4}\right)$. The organic layer was concentrated in vacuo and the resulting crude product was purified by flash chromatography to furnish the iodide 15 (160 mg, $0.29 \mathrm{mmol}, 66 \%)$

15: white solid. mp $154-155^{\circ} \mathrm{C}$ (Isopropyl ether).

$[\alpha]_{\mathrm{D}}^{19}=-37.2\left(\mathrm{c} 1.0, \mathrm{CHCl}_{3}\right)$.

IR (film): $v_{\text {máx }}\left(\mathrm{cm}^{-1}\right)=2920,1725(\mathrm{CO}$, broad $), 1710(\mathrm{CO}), 1450,1440,1320,1265,1205$, 1180, 1130, 1090, 1055, 1030, 965.

${ }^{1} \mathrm{H}$ NMR $\left(\mathrm{CDCl}_{3}, 200 \mathrm{MHz}\right): \delta=7.91-7.87(\mathrm{~m}, 2 \mathrm{H}$, aromatics $), 7.63-7.39(\mathrm{~m}, 4 \mathrm{H}$, aromatics, C-12 H), 5.22 (d, J=10.1 Hz, 1H, C-4 H), 4.84 (s, 1H, anomeric), 4.23-4.10 (m, 1H, C-5H), 3.67 (s, 3H, $\left.\mathrm{CO}_{2} \underline{\mathrm{CH}}_{3}\right), 3.54$ (s, 3H, $\left.\mathrm{OCH}_{3}\right), 3.39-3.13$ (m, 3H, C-6 H, C-7 H), 
$2.79\left(\mathrm{dd}, \mathrm{J}_{1}=10.4 \mathrm{~Hz}, \mathrm{~J}_{2}=7.3 \mathrm{~Hz}, 1 \mathrm{H}, \mathrm{C}-9 \mathrm{H}\right), 2.59-2.43\left(\mathrm{~m}, 1 \mathrm{H}, \mathrm{C}-8 \mathrm{H}_{\mathrm{a}}\right), 2.19(\mathrm{~d}, \mathrm{~J}=12.92$ $\mathrm{Hz}, 1 \mathrm{H}, \mathrm{C}-2 \mathrm{H}), 1.89\left(\mathrm{ddd}, \mathrm{J}_{1}=13.5 \mathrm{~Hz}, \mathrm{~J}_{2}=11.6 \mathrm{~Hz}, \mathrm{~J}_{3}=7.1 \mathrm{~Hz}, 1 \mathrm{H}, \mathrm{C}-8 \mathrm{H}_{\mathrm{b}}\right), 1.75(\mathrm{~d}, \mathrm{~J}=$ $1.5 \mathrm{~Hz}, 3 \mathrm{H}, \mathrm{C}-13 \mathrm{H})$.

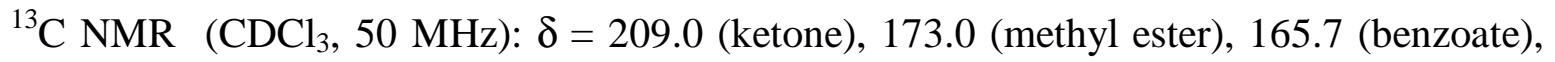
156.8 (C-12), 139.6 (C-11), 133.7 (aromatic), 129.7 (2C, aromatics), 128.6 (aromatic), 128.5 (2C, aromatics), $98.9(\mathrm{C}-1), 72.5(\mathrm{C}-4), 66.9$ (C-5), $55.9(\mathrm{C}-3), 55.7\left(\mathrm{OCH}_{3}\right), 54.0 *$ (C-9), 53.2* (C-2), $51.9\left(\mathrm{CO}_{2} \underline{\mathrm{CH}}_{3}\right), 48.0$ (C-7), 28.4 (C-8), 10.2 (C-13), 4.6 (C-6). (* = interchangeable)

Anal. Calcd for $\mathrm{C}_{23} \mathrm{H}_{25} \mathrm{IO}_{7}$ : C 51.12, H 4.66, O 20.73; Found C 51.23, H 4.75.
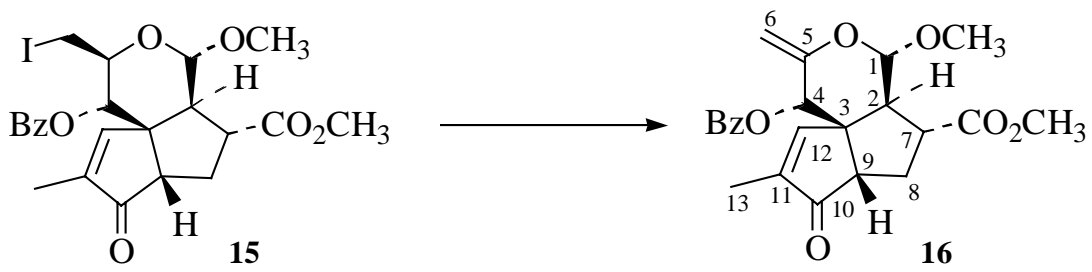

Enol ether 16. The iodide 15 (233.8 mg, $0.433 \mathrm{~mol})$ was dissolved in dry pyridine (5 ml) and AgF (171.4 mg, $1.351 \mathrm{mmol})$ was added. The mixture was stirred for $12 \mathrm{~h}$ protected from the light at room temperature. After complete reaction, the mixture was filtered with suction through a filter funnel with a porosity E sintered glass fritted disc with celite and suction. Toluene was added to the filtrate and concentrated under reduced pressure (to remove all of the pyridine). The resulting syrup was purified by flash chromatography to furnish the enol ether 16 in $94 \%$ yields $(168.9 \mathrm{mg}, 0.40 \mathrm{mmol})$

16: white solid. mp $210-212^{\circ} \mathrm{C}$ (Petroleun ether).

$[\alpha]_{\mathrm{D}}^{24}=-42.3\left(\mathrm{c} 0.975, \mathrm{CHCl}_{3}\right)$.

IR (film): $v_{\text {máx }}\left(\mathrm{cm}^{-1}\right)=2940,2925,2825,1729(\mathrm{CO}$, broad $), 1710(\mathrm{CO}), 1665,1452,1318$, 1269, 1201, 1111, 1028, 978. 
${ }^{1} \mathrm{H}$ NMR $\left(\mathrm{CDCl}_{3}, 200 \mathrm{MHz}\right): \delta=8.03-8.00(\mathrm{~m}, 2 \mathrm{H}$, aromatics $), 7.63-7.37(\mathrm{~m}, 4 \mathrm{H}$, aromatics, C-12 H), 5.70 (s, 1H, C-4 H), $4.93(\mathrm{~d}, \mathrm{~J}=2.44 \mathrm{~Hz}, 1 \mathrm{H}$, anomeric), 4.74 (s, 1H, C-6a H), 4.55 (s, 1H, C-6b H), 3.68 (s, $\left.3 \mathrm{H}, \mathrm{CO}_{2} \mathrm{C}_{3}\right), 3.50$ (s, 3H, $\left.\mathrm{OCH}_{3}\right), 3.21$ (dd, $\mathrm{J}_{1}=$ $\left.17.0 \mathrm{~Hz}, \mathrm{~J}_{2}=9.4 \mathrm{~Hz}, 1 \mathrm{H}, \mathrm{C}-7 \mathrm{H}\right), 2.73\left(\mathrm{dd}, \mathrm{J}_{1}=9.9 \mathrm{~Hz}, \mathrm{~J}_{2}=6.6 \mathrm{~Hz}, 1 \mathrm{H}, \mathrm{C}-9 \mathrm{H}\right), 2.50\left(\mathrm{dd}, \mathrm{J}_{1}=\right.$ $\left.9.7 \mathrm{~Hz}, \mathrm{~J}_{2}=2.44 \mathrm{~Hz}, 1 \mathrm{H}, \mathrm{C}-2 \mathrm{H}\right), 2.45-2.36\left(\mathrm{~m}, 1 \mathrm{H}, \mathrm{C}-8 \mathrm{H}_{\mathrm{a}}\right), 2.11-1.96\left(\mathrm{~m}, 1 \mathrm{H}, \mathrm{C}-8 \mathrm{H}_{\mathrm{b}}\right)$, $1.75(\mathrm{~d}, \mathrm{~J}=1.3 \mathrm{~Hz}, 3 \mathrm{H}, \mathrm{C}-13 \mathrm{H})$.

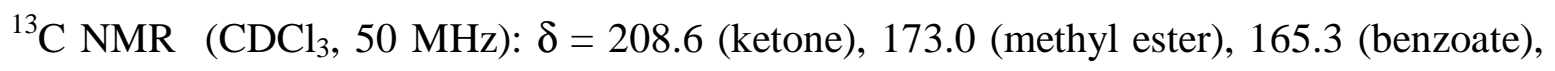
157.1 (C-12), 151.1 (C-5), 140.4 (C-11), 133.5 (aromatic), 129.7 (2C, aromatics), 129.1 (aromatic), 128.5 (2C, aromatics), 100.9 (C-1), 95.2 (C-6), 70.0 (C-4), 56.0 (C-3), 55.7 $\left(\mathrm{OCH}_{3}\right), 54.0 *(\mathrm{C}-9), 52.0\left(\mathrm{CO}_{2} \underline{\mathrm{CH}}_{3}\right), 51.0 *(\mathrm{C}-2), 48.4(\mathrm{C}-7), 29.4(\mathrm{C}-8), 10.1(\mathrm{C}-13) .{ }^{*}=$ interchangeable)

HRMS m/z 412.15137 [ $\left(\mathrm{M}^{+}\right)$; calcd for $\left.\mathrm{C}_{23} \mathrm{H}_{24} \mathrm{O}_{7}: 412.15220\right]$.
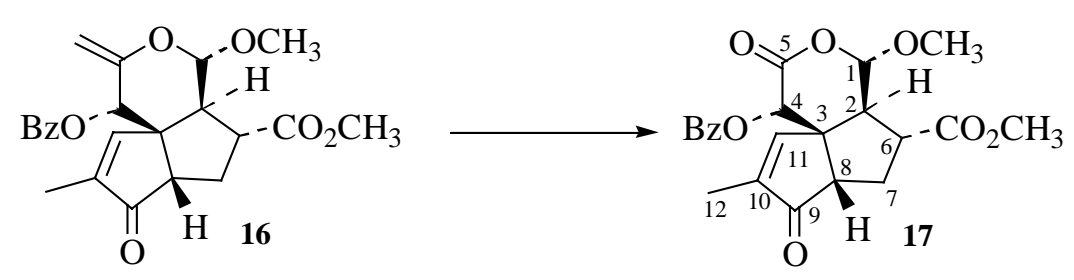

Alcoxy-lactone 17. A solution of enol ether $16(168.9 \mathrm{mg}, 0.410 \mathrm{mmol})$ in dry dichloromethane $(12 \mathrm{ml})$ was cooled to $-78^{\circ} \mathrm{C}$, and ozone stream was bubbled through it at $-78^{\circ} \mathrm{C}$ for 30 min until complete consumption of $\mathbf{1 6}$ was observed by TLC analysis. The solution was then flushed with argon and dimethyl sulfide $(0,510 \mathrm{ml})$ was added to $-78^{\circ} \mathrm{C}$. The reaction mixture was allowed to warm to room temperature and the volatiles were removed in vacuo to afford $170 \mathrm{mg}$ of the alcoxy-lactone $\mathbf{1 7}$ essentially pure.

17: colorless solid. mp $161-162{ }^{\circ} \mathrm{C}(\mathrm{MeOH})$.

$[\alpha]_{\mathrm{D}}{ }^{19}=+9.7\left(\mathrm{c} 5.05, \mathrm{CHCl}_{3}\right)$. 
IR (film): $v_{\text {máx }}\left(\mathrm{cm}^{-1}\right)=2949,2925,2853,1772$ (CO), 1732 (CO), 1716 (CO), 1453, 1266, $1208,1175,1115,985,957,708$.

${ }^{1} \mathrm{H}$ NMR $\left(\mathrm{CDCl}_{3}, 200 \mathrm{MHz}\right): \delta=7.93-7.89(\mathrm{~m}, 2 \mathrm{H}$, aromatics $), 7.63-7.39(\mathrm{~m}, 3 \mathrm{H}$, aromatics), 7.09 (d, J= 1.3 Hz, 1H, C-11 H), $5.67(\mathrm{~s}, 1 \mathrm{H}, \mathrm{C}-4 \mathrm{H}), 5.38$ (d, J= $8.8 \mathrm{~Hz}, 1 \mathrm{H}$, anomeric), 3.65 (s, $\left.3 \mathrm{H}, \mathrm{CO}_{2} \underline{\mathrm{C}}_{3}\right), 3.63\left(\mathrm{~s}, 3 \mathrm{H}, \mathrm{OCH}_{3}\right), 3.09$ (dd, $\mathrm{J}_{1}=12.9 \mathrm{~Hz}, \mathrm{~J}_{2}=6.7 \mathrm{~Hz}$, 1H, C-6 H), 2.91-2.75 (m, 2H, C-8 H, C-7 Ha), 2.44-2.34 (m, 2H, C-2 H, C-7 Hb), 1.84 (d, $\mathrm{J}=1.3 \mathrm{~Hz}, 3 \mathrm{H}, \mathrm{C}-12 \mathrm{H})$.

${ }^{13} \mathrm{C} \mathrm{NMR}\left(\mathrm{CDCl}_{3}, 50 \mathrm{MHz}\right): \delta=207.0$ (ketone), 172.6 (methyl ester), 165.9* (lactone), 165.3* (benzoate), 154.3 (C-11), 142.0 (C-10), 133.8 (aromatic), 129.7 (2C, aromatics), 128.4 (2C, aromatics), 128.1 (aromatic), 103.2 (C-1), $69.7(\mathrm{C}-4), 57.7\left(\mathrm{OCH}_{3}\right), 55.4(\mathrm{C}-3)$, $54.3^{*}(\mathrm{C}-8), 52.1\left(\mathrm{CO}_{2} \mathrm{CH}_{3}\right), 51.9^{*}(\mathrm{C}-2), 48.0(\mathrm{C}-6), 31.0(\mathrm{C}-7), 9.9(\mathrm{C}-12) .{ }^{*}=$ interchangeable)

HRMS m/z 415.139000 [(M + $\left.\mathrm{H}^{+}\right)$; calcd for $\left.\mathrm{C}_{22} \mathrm{H}_{22} \mathrm{O}_{8}: 415.13930\right]$.

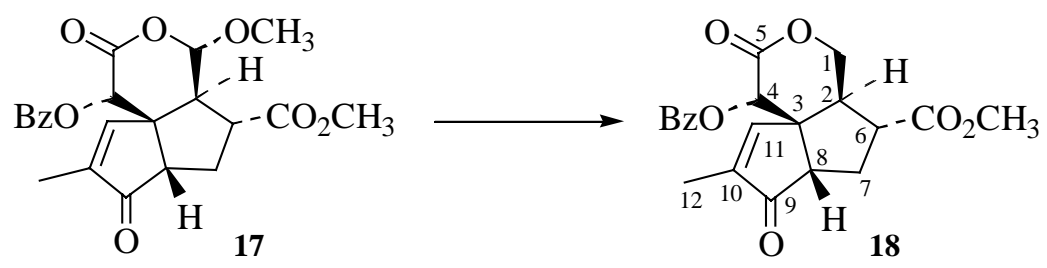

Lactone 18. The alcoxy-lactone $17(68.8 \mathrm{mg}, 0.166 \mathrm{mmol})$ was dissolved in dry dichloromethane $(6 \mathrm{ml})$ and cooled to $0^{\circ} \mathrm{C}$. Triethylsilane $(0.242 \mathrm{ml}, 1.495 \mathrm{mmol})$ and boron trifluoride etherate $(72 \mu \mathrm{l}, 0.563 \mathrm{mmol})$ were sequentially added. The reaction mixture was allowed to warm to room temperature and was stirred for $20 \mathrm{~h}$. After complete reaction, the mixture was diluted with AcOEt, washed with brine and dried $\left(\mathrm{Na}_{2} \mathrm{SO}_{4}\right)$. The volatiles were removed under reduced pressure to afford $64 \mathrm{mg}$ of the lactone $\mathbf{1 8}$ essentially pure. 
18: white solid. mp. $214-215^{\circ} \mathrm{C}(\mathrm{MeOH})$.

$[\alpha]_{\mathrm{D}}{ }^{27}=-29.37\left(\mathrm{c} 0.8, \mathrm{CHCl}_{3}\right)$.

IR (film): $v_{\text {máx }}\left(\mathrm{cm}^{-1}\right)=2954,2923,2852,1762$ (CO), 1726 (CO), 1702 (CO), 1451, 1265, $1252,1117,1024,842,707$.

${ }^{1} \mathrm{H}$ NMR $\left(\mathrm{CDCl}_{3}, 200 \mathrm{MHz}\right): \delta=7.93-7.88(\mathrm{~m}, 2 \mathrm{H}$, aromatics $), 7.62-7.38(\mathrm{~m}, 3 \mathrm{H}$, aromatics), $7.06(\mathrm{~d}, \mathrm{~J}=1.3 \mathrm{~Hz}, 1 \mathrm{H}, \mathrm{C}-11 \mathrm{H}), 5.83(\mathrm{~s}, 1 \mathrm{H}, \mathrm{C}-4 \mathrm{H}), 4.64\left(\mathrm{dd}, \mathrm{J}_{1}=11.9 \mathrm{~Hz}\right.$, $\left.\mathrm{J}_{2}=6.7 \mathrm{~Hz}, 1 \mathrm{H}, \mathrm{C}-1 \mathrm{H}_{\mathrm{a}}\right), 4.36\left(\mathrm{t}, \mathrm{J}_{1}=11.9 \mathrm{~Hz}, 1 \mathrm{H}, \mathrm{C}-1 \mathrm{H}_{\mathrm{b}}\right), 3.66\left(\mathrm{~s}, 3 \mathrm{H}, \mathrm{CO}_{2} \mathrm{C}_{3}\right), 3.00-2.93$ (m, 2H, C-2 H, C-6 H), 2.84 (dd, J $\left.=9.0 \mathrm{~Hz}, \mathrm{~J}_{2}=7.1 \mathrm{~Hz}, 1 \mathrm{H}, \mathrm{C}-8 \mathrm{H}\right), 2.58-2,43$ (m, 1H, C-7 $\left.\mathrm{H}_{\mathrm{a}}\right), 2.25-2.10\left(\mathrm{~m}, 1 \mathrm{H}, \mathrm{C}-7 \mathrm{H}_{\mathrm{b}}\right), 1.85(\mathrm{~d}, \mathrm{~J}=1.3 \mathrm{~Hz}, 3 \mathrm{H}, \mathrm{C}-12 \mathrm{H})$.

${ }^{13} \mathrm{C} \mathrm{NMR}\left(\mathrm{CDCl}_{3}, 50 \mathrm{MHz}\right): \delta=206.8$ (ketone), 172.2 (methyl ester), 167.5* (lactone), 165.3* (benzoate), 154.7 (C-11), 141.7 (C-10), 133.8 (aromatic), 129.7 (2C, aromatics), 128.5 (2C, aromatics), 128.3 (aromatics), 69.6 (C-4), 67.9 (C-1), 57.3 (C-3), 53.9* (C-8), $52.3\left(\mathrm{CO}_{2} \mathrm{CH}_{3}\right), 49.1 *(\mathrm{C}-2), 45.2(\mathrm{C}-6), 31.2(\mathrm{C}-7), 10.0(\mathrm{C}-12) .{ }^{*}=$ interchangeable $)$ Anal. Calcd for $\mathrm{C}_{21} \mathrm{H}_{20} \mathrm{O}_{7}$ : C 65.62, H 5.24, O 29.14; Found C 65.33, H 5.16. 


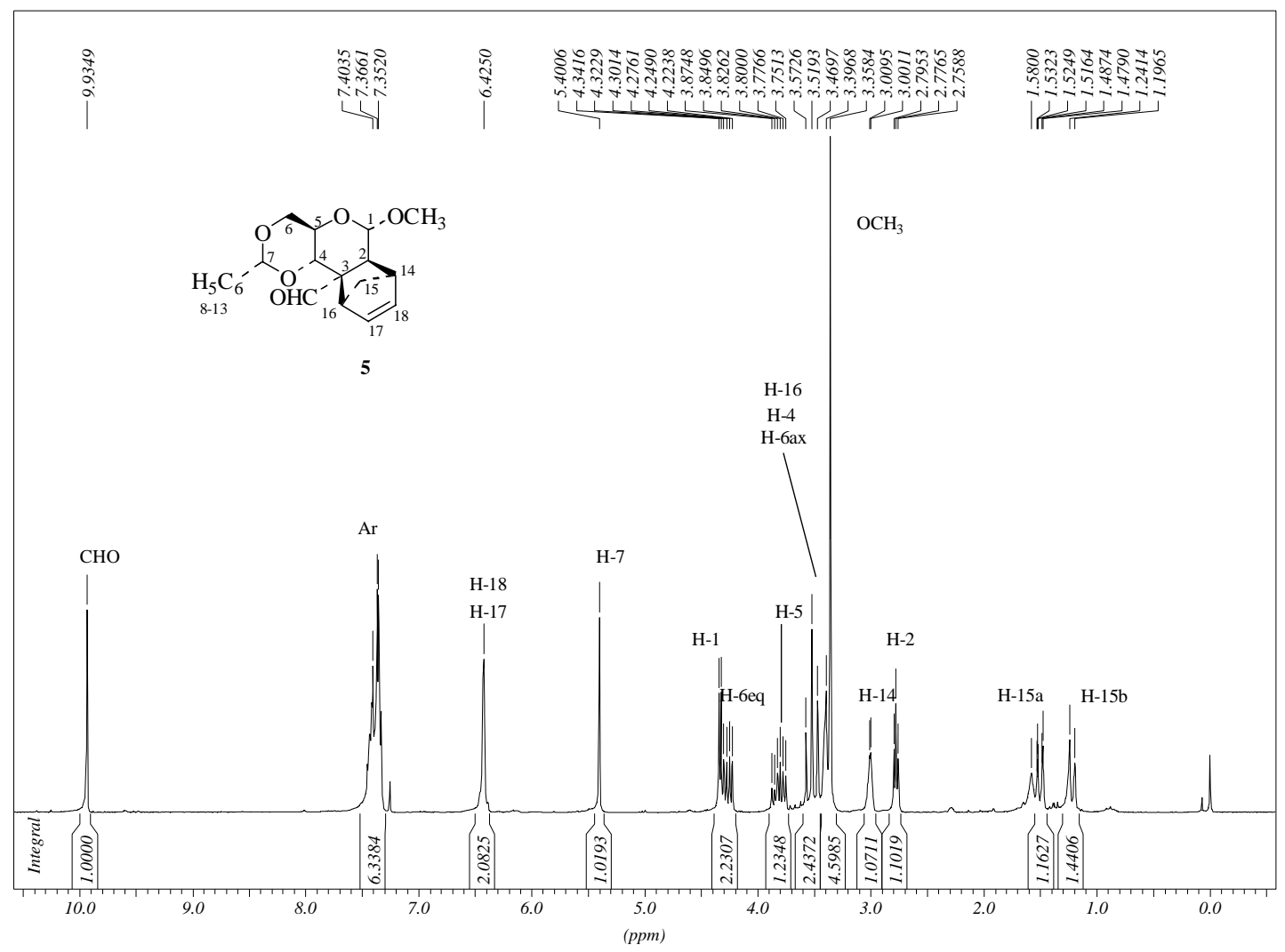




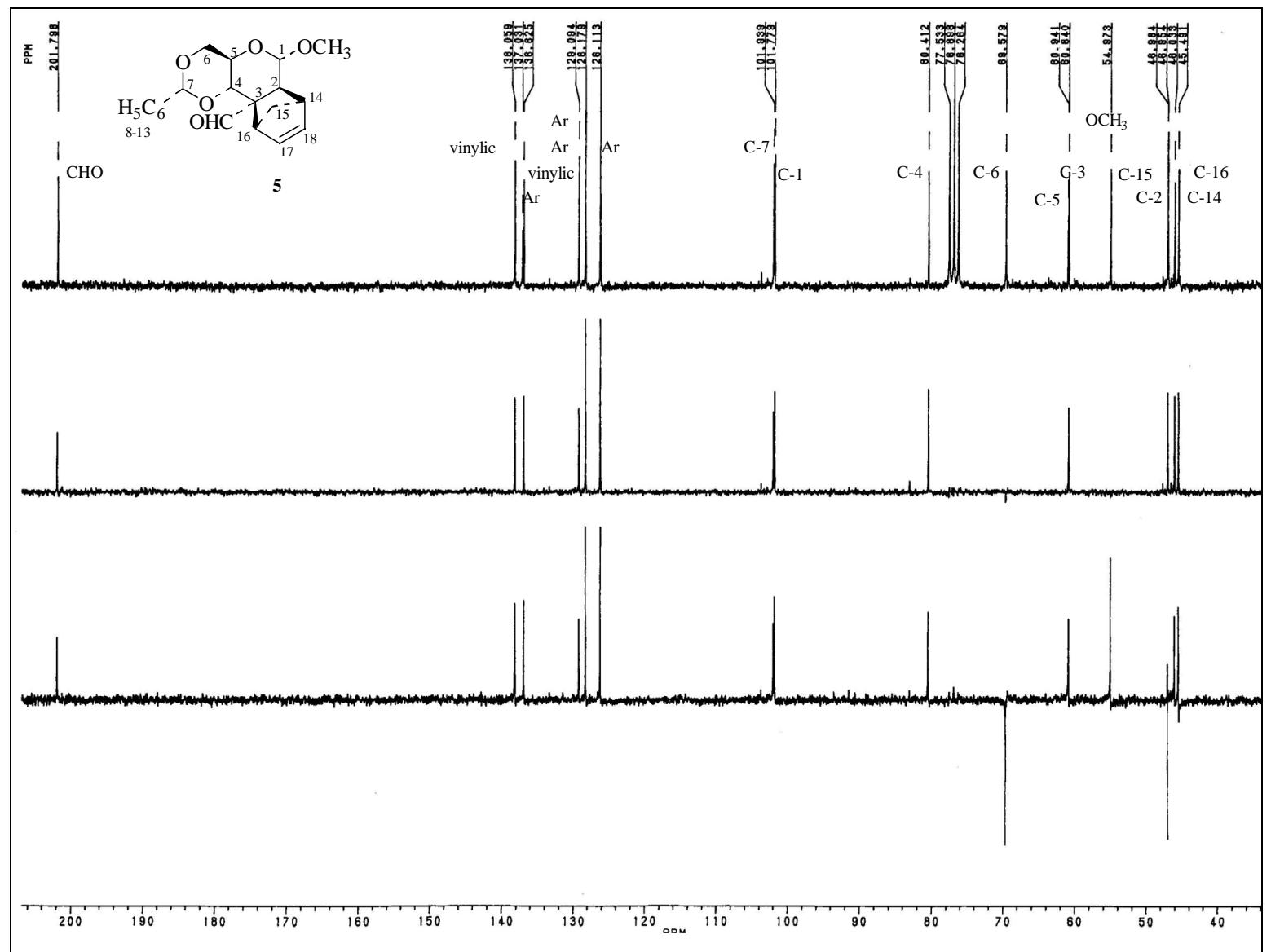




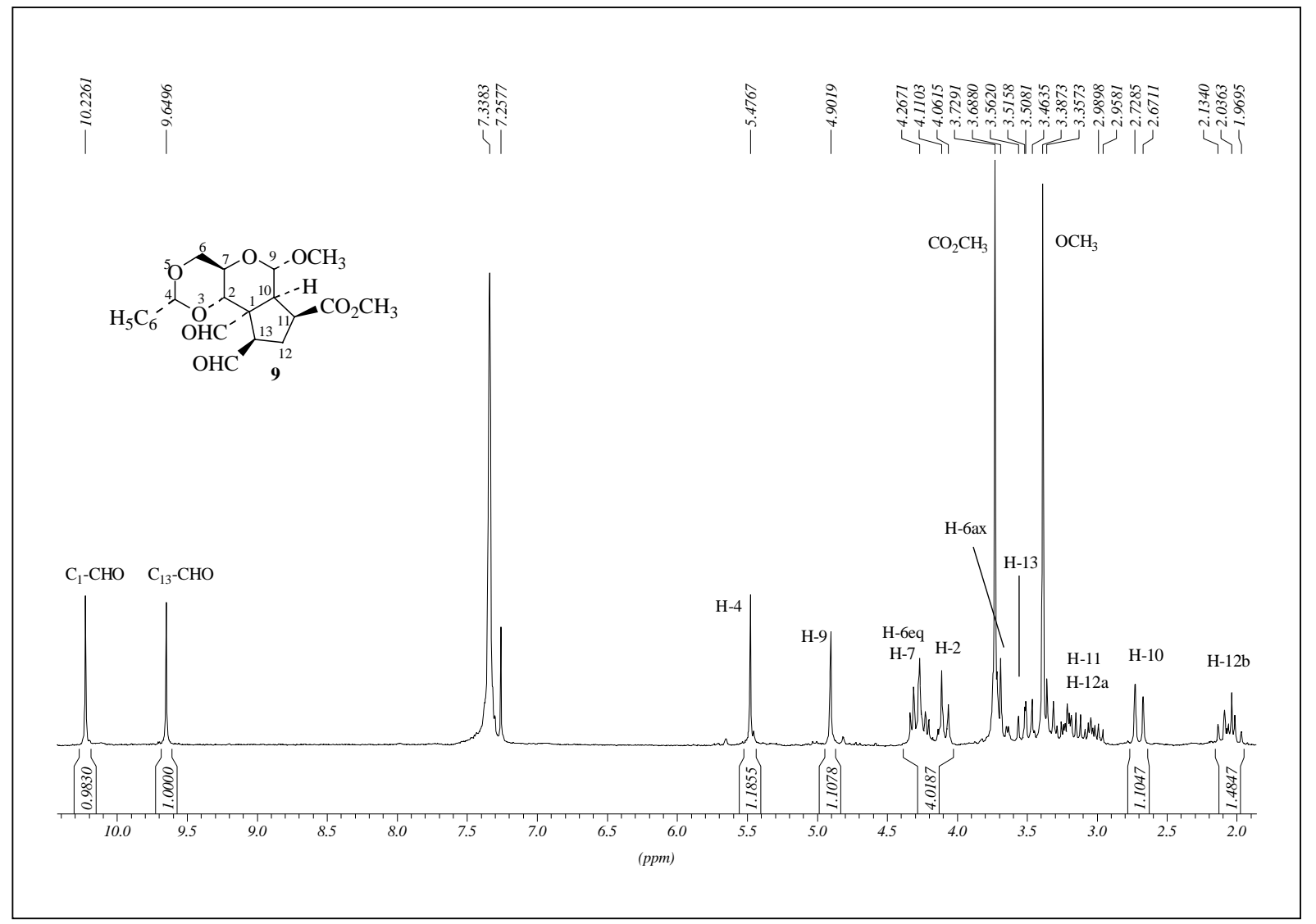




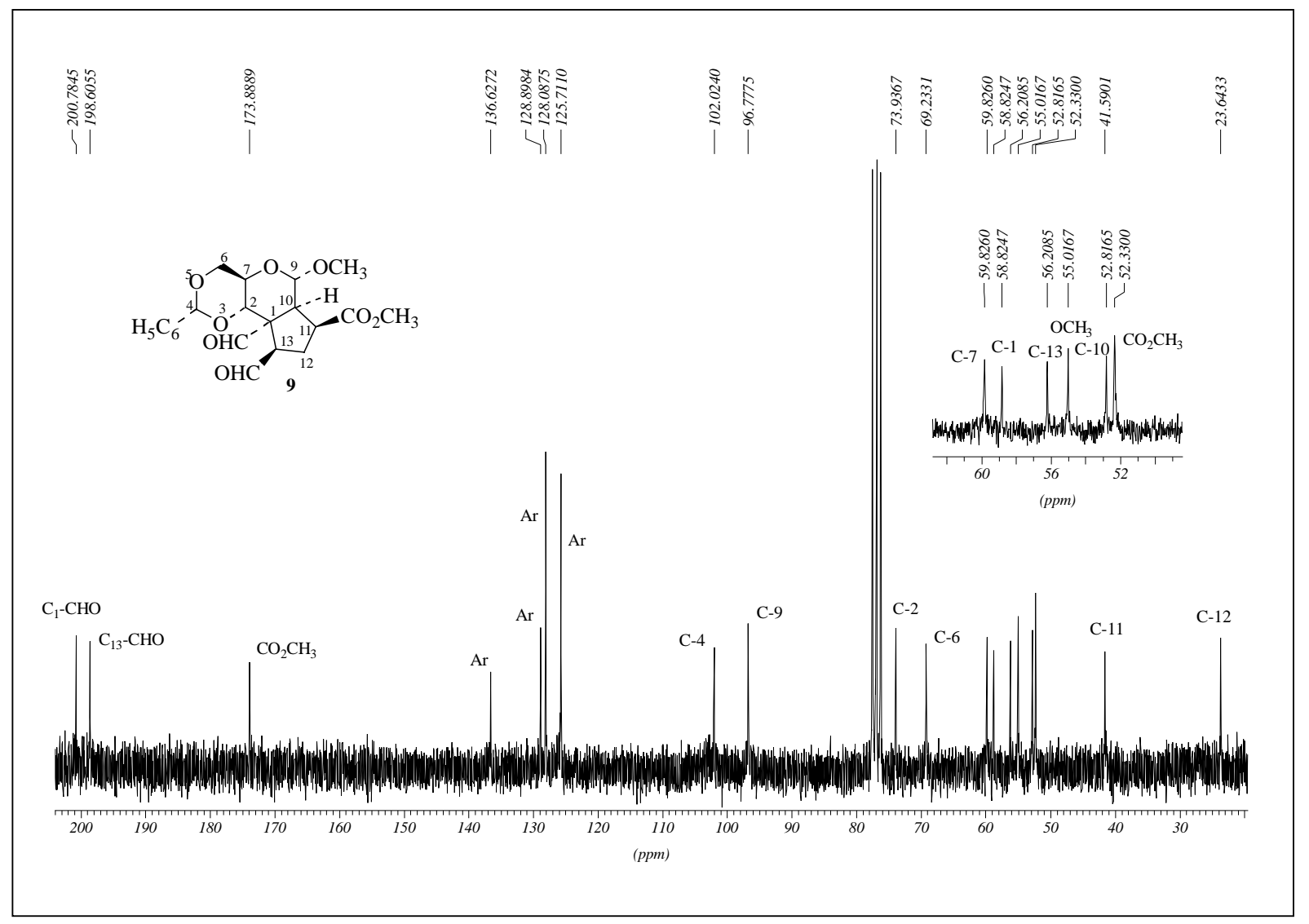



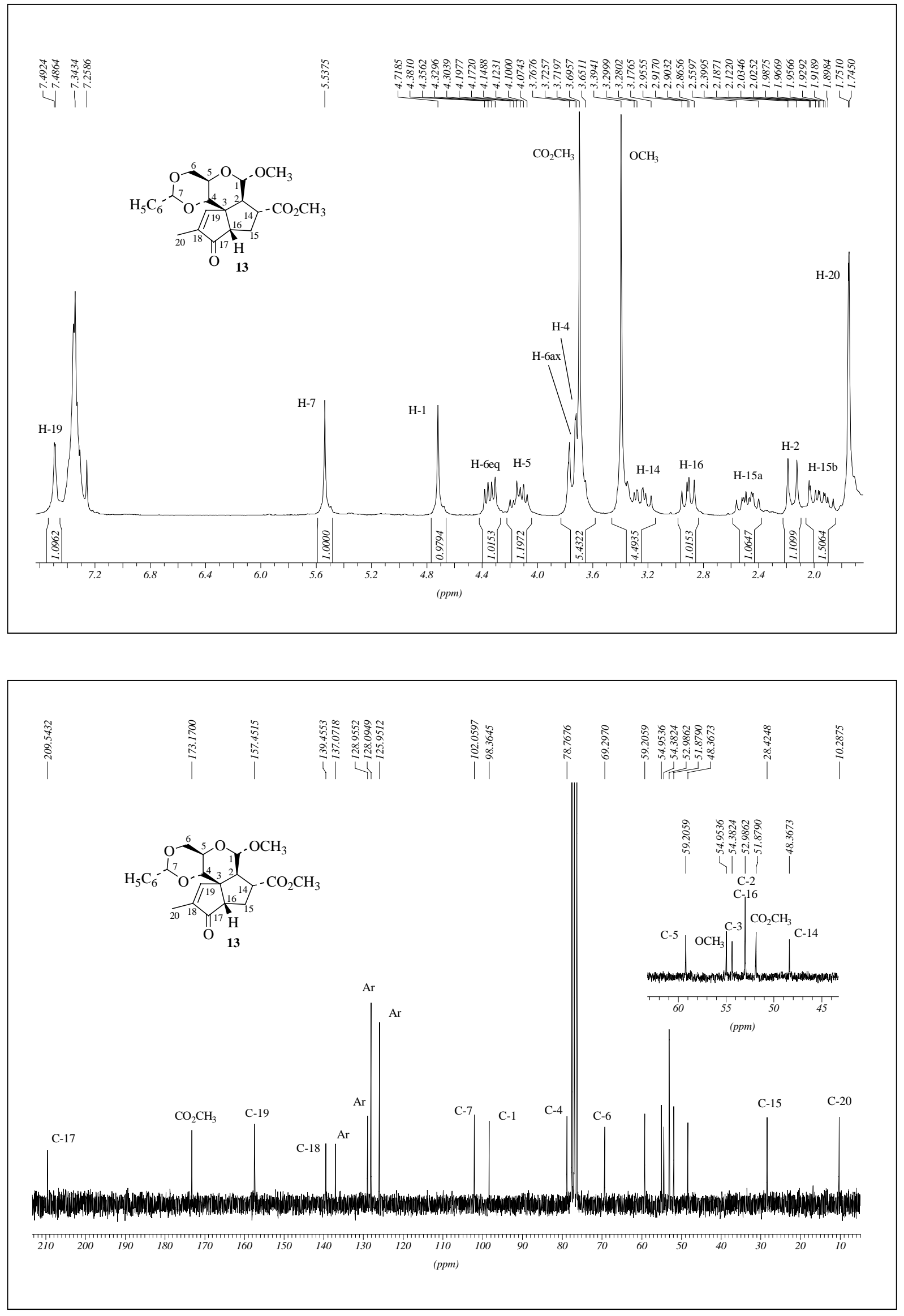

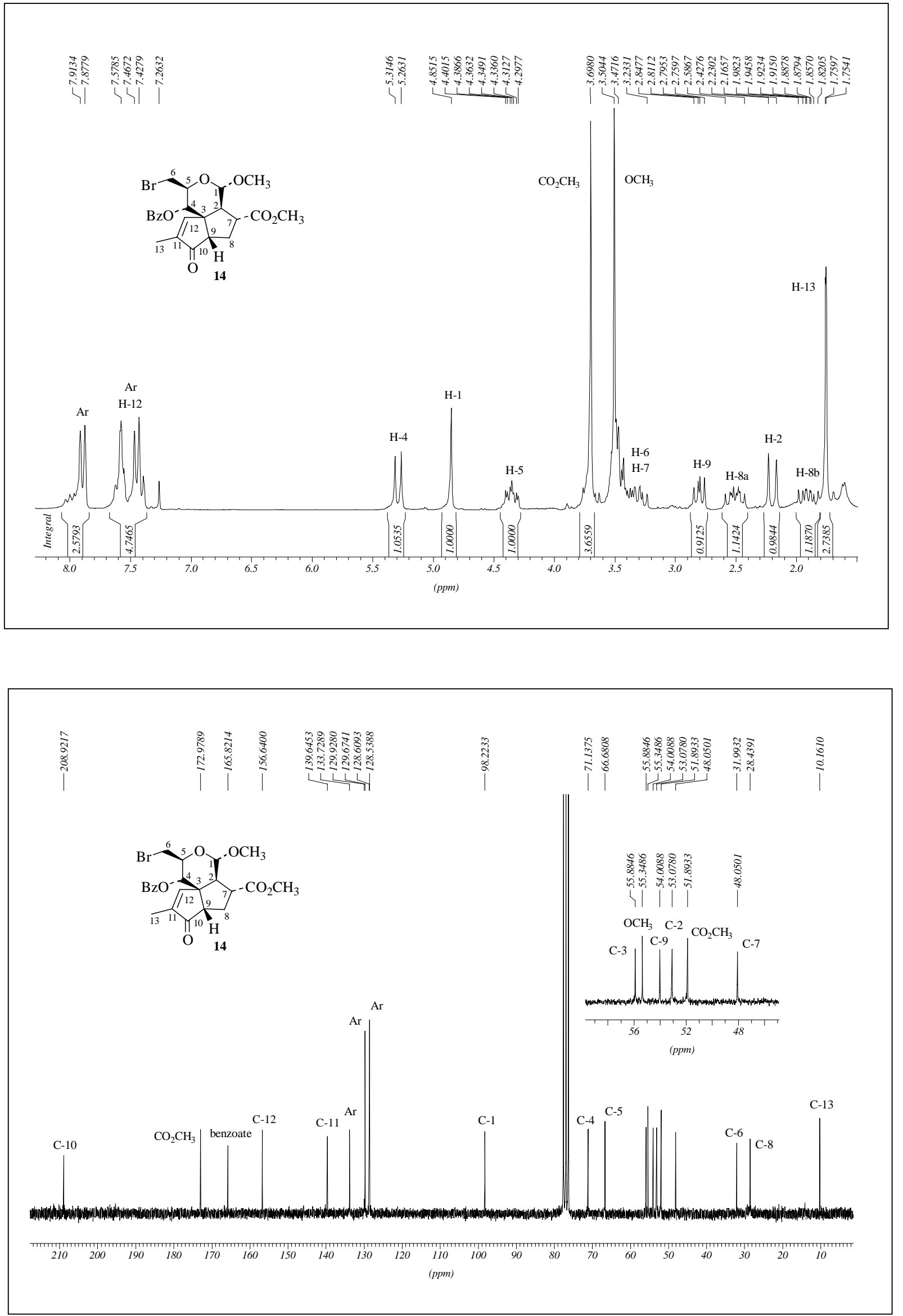

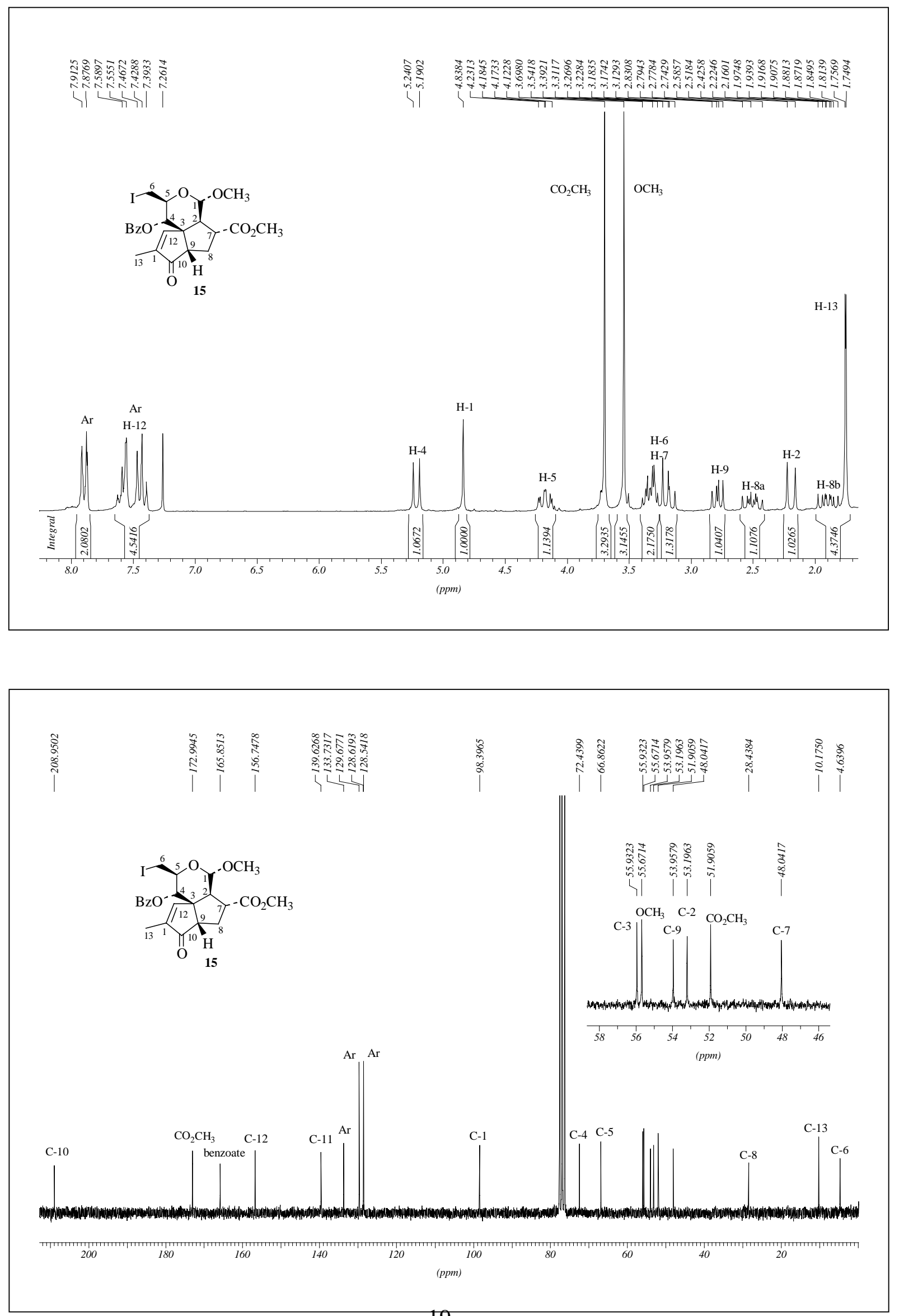

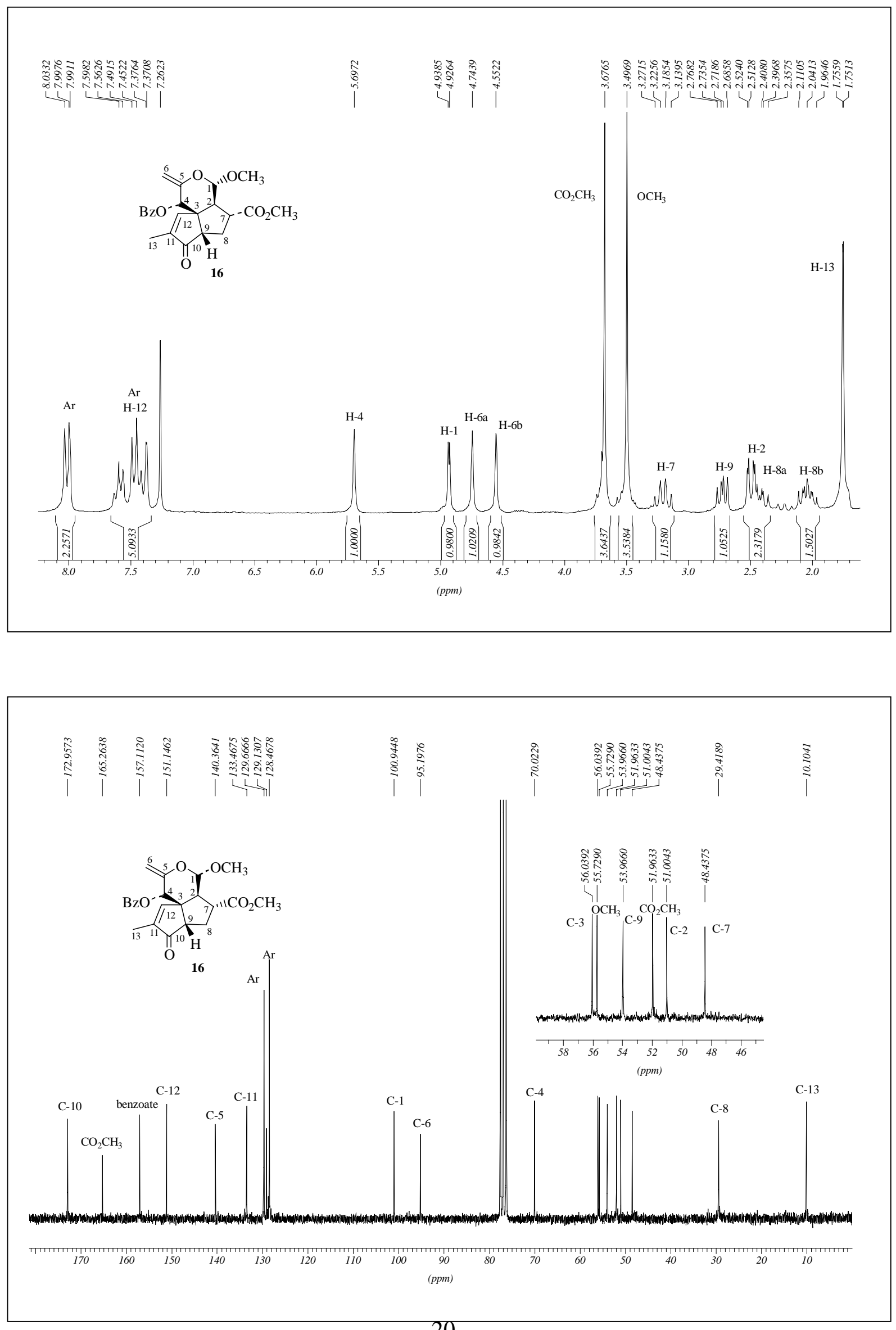

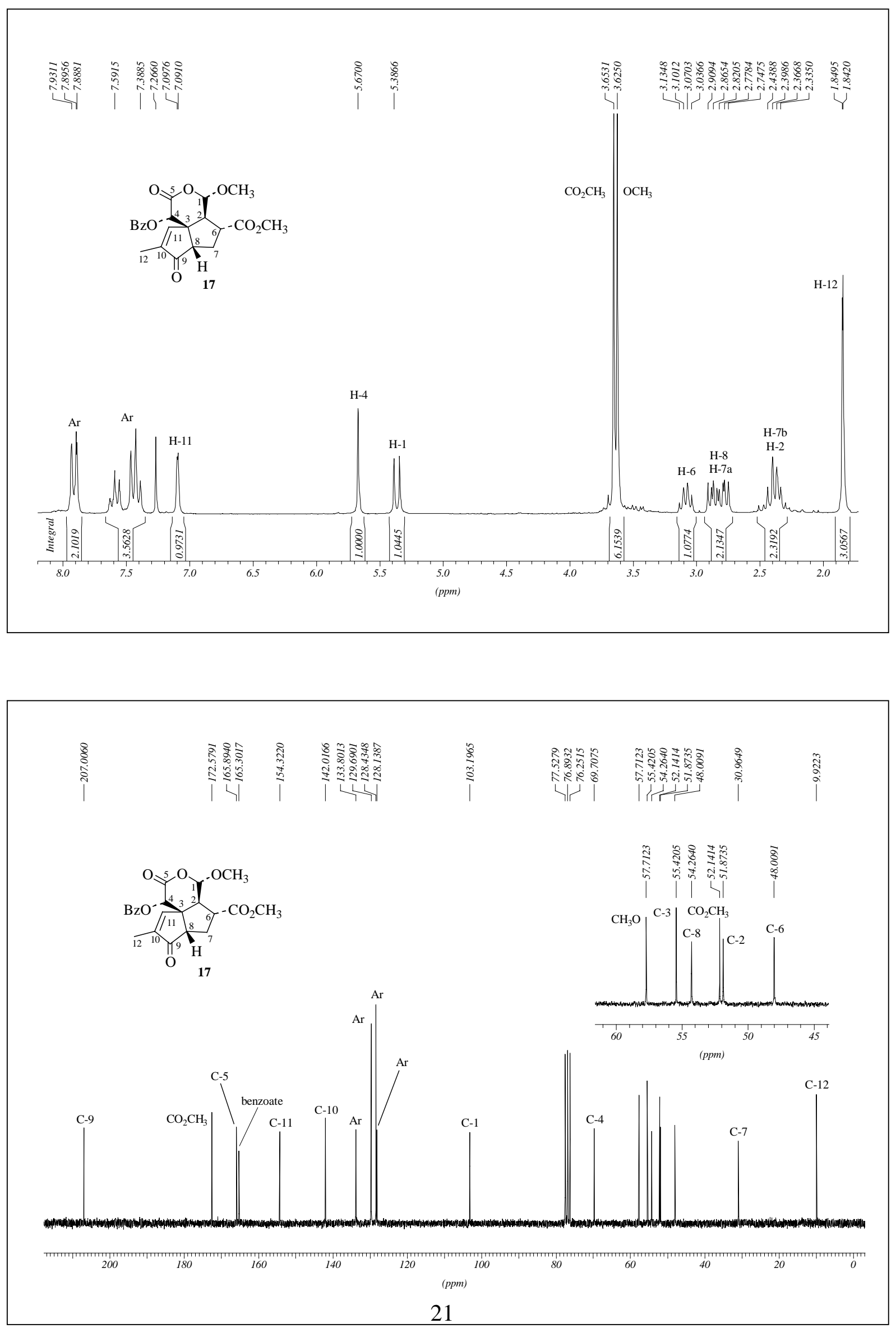

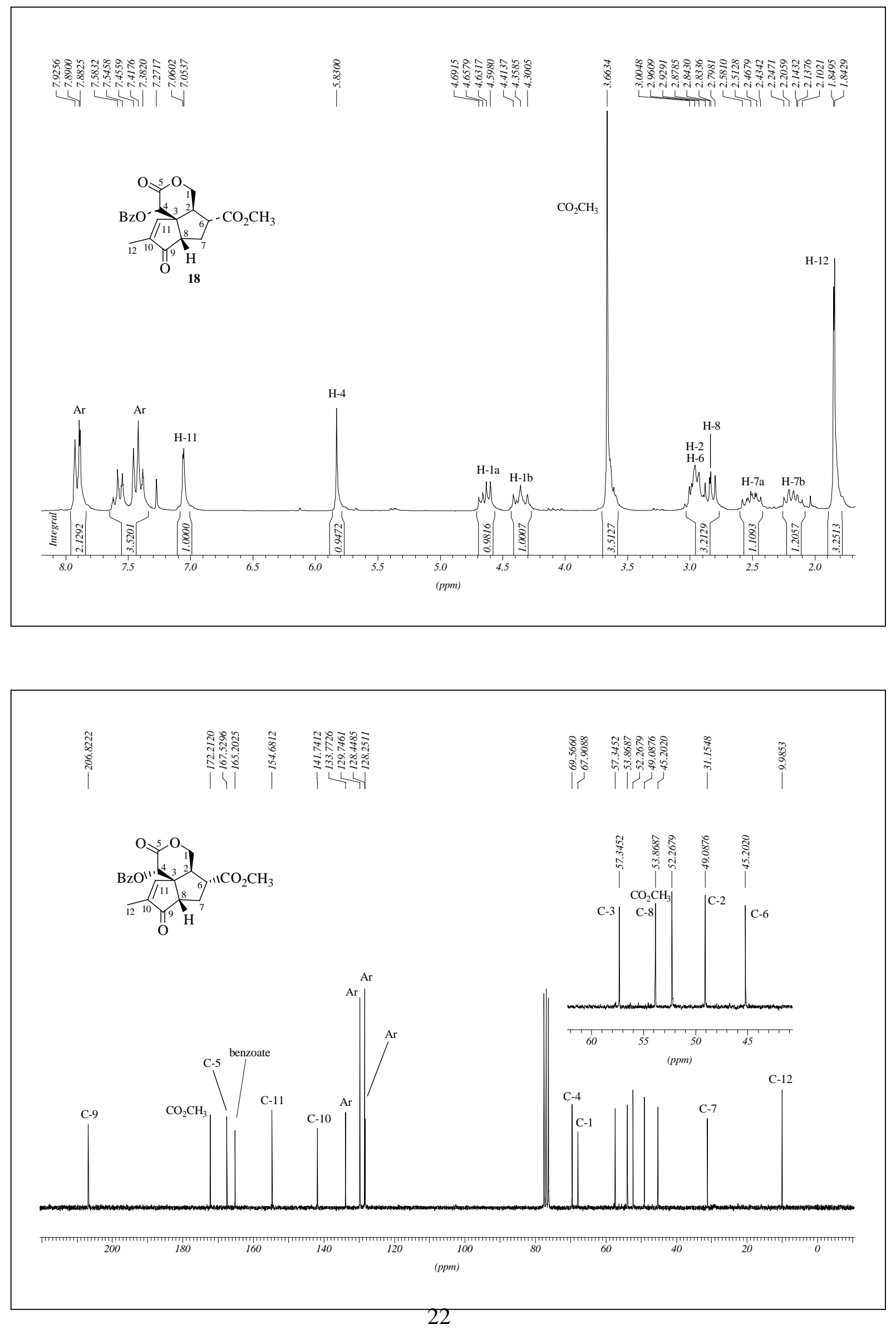